place communicated with during that time was Gibraltar, and then only to receive a supply of provisions and water from the dockyard. The yellow fever unfortunately breaking out at Gibraltar just before going there for this object, no communication could be had with the town, and the stay was confined to from twenty-four to forty-eight hours. The zeal and ability with which this service was carried out by Capt. Manners, as witnessed by Sir George Sartorius, there in command of the Portuguese Constitutional Squadron, and under whose orders in some degree the Britomart was placed, led to Capt Manners receiving his Post-rank on the 4 th of March, 1829. He retired from active service in March I849, became Rear-Admiral in July 1855 , Vice-Admiral in April 1862 , and Admiral in September 1865 .

Admiral Manners was the only child of the late Mr. Russell Manners, M.P., and married in 1834 Louisa Jane, daughter of Count de Noé, Peer of France, who survives him, and by whom he has two sons and a daughter.

From the time he attained his Post-rank to the time of his death he devoted himself to scientific pursuits. He was elected a member of the Royal Astronomical Society in 1836 . At a very early period he took an active interest in its administration, and after being on the Council for some time, was elected one of the honorary secretaries in February 1848 , an office which he filled until 1858 , when he accepted that of Foreign Secretary. This was a post for which his knowledge of foreign languages and his position in society peculiarly fitted him, and during his tenure of office he formed by active correspondence a connecting link between English and foreign astronomers. He was much esteemed abroad, so much so indeed that one of the presidents, in asking Admiral Manners to transmit one of the Society's medals to a foreign recipient, deemed it just to preface his remarks with the following well-deserved compliment :-

"Admiral Manners, - It has been my good fortune to visit the majority of European Observatories, and to make the acquaintance of their directors and other gentlemen connected with them, and it has in consequence become known to me how high in their esteem our Foreign Secretary stands. Your urbanity and promptitude in carrying out our foreign business has indeed become proverbial."

Admiral Manners was, on more than one occasion, asked to accept the chair of President, which, after some hesitation, he consented to do, and he was elected to that position in 1868. None of his predecessors was more highly esteemed by the Fellows of the Society, and no one filled the chair more admirably than he did. His mathematical attainments were considerable, more so than one might be apt to infer from his quiet demeanour. $\mathrm{He}$ was well versed in the astronomical literature of the day, and took a deep interest in the progress of astronomical science, both in England and on the Continent; and his active influence was always available for the promotion of any object connected with it.

On presenting the gold medal of the Society to $\mathrm{Mr}$. Stone, first assistant of the Royal Observatory, Greenwich,Admiral Manners delivered a mostable and exhaustive summary of that able astronomer's labours, and evinced a complete knowledge of the history of the solar parallax, for the investigation of which the medal was mainly awarded. Illness overtook him before he could complete his second year of office, and he was compelled to forego the gratification of delivering the address to $M$. Delaunay for his researches on the lunar theory; but he made it a point of duty and pleasure to receive $M$. Delaunay at his house, and although he was compelled to delegate to the friendly hand of Prof. Adams the drawing up of the address, yet he read and approved of what was written before it was delivered.

Admiral Manners in all his relations was a pure-minded, courteous, and sympathetic man, and in the fullest sense of the word a gentleman.

\section{THE PRIMITIVE VEGETATION OF THE EARTH}

TWENTY years ago scarcely anything was known, even to those engaged in the study of vegetable fossils, of a land flora older than the great coal-formation. In I86́, Goeppert, in his Memoir on the plants of the Silurian, Devonian, and Lower Carboniferous, mentions only one land plant, and this of doubtful character, in the Lower Devonian. In the Middle Devonian he knew but one species; in the Upper Devonian he enumerated fifty-seven. Most of these were European, but he included also such American species as were known to him. The paper of the writer on the Land Plants of Gaspé was published in I 859, but had not reached Goeppert at the time when his memoir was written. This, with some other descriptions of American Devonian plants not in his possession, might have added ten or twelve species, some of them Lower Devonian, to his list. In the ten years from 1860 to the present time, the writer has been able to raise the Devonian flora of Eastern North America to I2I species, and reckoning those of Europe at half that number, we now have at least 180 species of land plants from the Devonian, besides a few from the Upper Silurian. We thus have presented to our view a flora older than that of the Carboniferous period, and, in many respects, distinct from it ; and in connection with which many interesting geological and botanical questions arise.

Geologists are aware that in passing backward in geological time from the modern to the Palæozoic period, we lose, as dominant members of the vegetable kingdom, first, the higher phænogamous plants, whether exogenous or endogenous; and that, in the Mesozoic period, the Acrogens, or higher cryptogams, represented by Ferns, Club-mosses, and Equiseta, share the world with the Gymnosperms, represented by the Pines and Cycads, while the higher phænogams on the one hand, and the lower cryptogams on the other, are excluded. Hence, the Mesozoic age has been called that of Gymnosperms, while the Palæozoic is that of Acrogens. These names are not, however, absolutely accurate, as we shall see that one of the highest forms of modern vegetation can be traced back into the Devonian; though the terms are undoubtedly useful, as indicating the prevalence of the types above mentioned, in a degree not now observed, and a corresponding rarity of those forms which constitute our prevalent modern vegetation.

It is my present object shortly to sketch the more recent facts of Devonian and Upper Silurian Botany, and to refer to a few of the general truths which they teach. The rocks called Devonian in Europe being on the horizon of the Erie division of the American geologists, which are much more fully developed than their representatives on the Eastern Continent, I shall use the term Erian as equivalent to Devonian, understanding by both that long and important geological age intervening between the close of the Upper Silurian and the beginning of the Carboniferous.

Just as in Europe the rocks of this period present a twofold aspect, being in some places of the character of a deposit of "Old Red Sandstone," and in others indicating deeper water, or more properly marine conditions, so in America, on a greater scale, they have two characters of development. In the great and typical Erian area, extending for 700 miles to the westward of the Apalachian chain of mountains, these rocks, sometimes attaining to a thickness of 15,000 feet, include extensive marine deposits; and except in their north-eastern border are not rich in fossil plants. In the smaller north-eastern area, on the other hand, lying to the eastward of the Apalachian range, they consist wholly of sandstones and shales, and are rich in plant remains while poor in marine fossils. Hence it is the Devonian of Gaspé, of New Brunswick, and of Maine, with that of eastern New York, 
which have chiefly afforded the plants to be described below; and it is exclusively in these areas that we find underclays with roots, or true fossil soils. Most of the localities of fossil plants in the districts above mentioned have been visited, and their plants studied $i n$ situ by the writer. The Gaspé sandstones were first studied and carefully measured and mapped by Sir W. E. Logan. The Devonian beds of St. John's, New Brunswick, have been thoroughly examined and illustrated by Prof. Hartt and Mr. Matthews, and those of Perry by Prof. Jackson, Prof. Rogers, and Mr. Hitchcock. Prof. Hall, of the Survey of New York, has kindly communi-

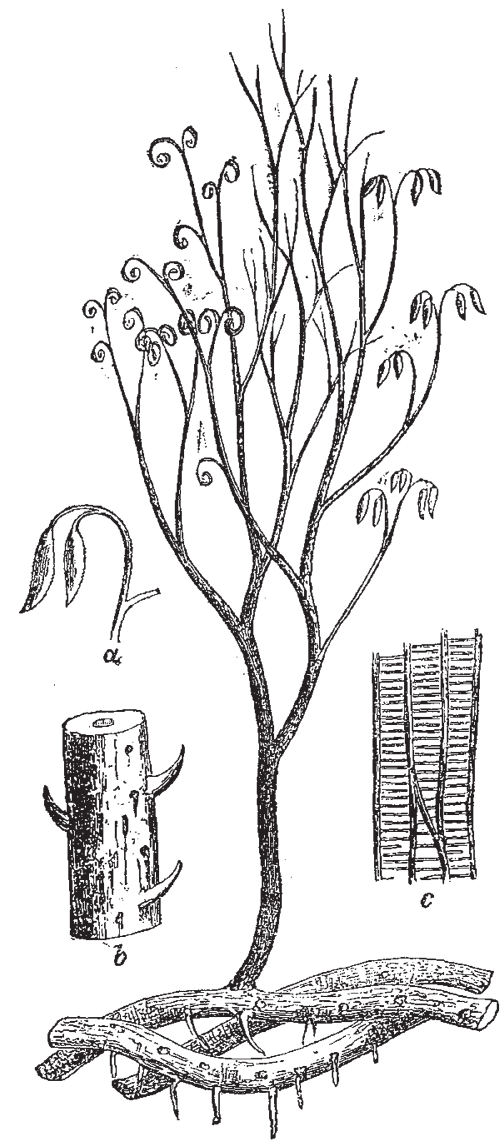

FIG. 1.-Psilophyton princeps - the oldest known plant of America, restored. $(a)$, Fruit, natural size; (b), Stem, natural size; (c), Scalariform tissue of the axis, highly magnifed, in vernation, and the other in fruit.

cated to me the plants found in that State, and Prof. Newberry has contributed some facts and specimens illustrative of those of Ohio.

In the Sandstone cliffs of Gaspé Bay, Sir W. E. Logan recognised in 1843 the presence of great numbers of apparent roots in some of the shales and fine saridstones. These roots had evidently penetrated the beds in a living state, so that the root-beds were true fossil soils, which, after supporting vegetation, became submerged and covered with new beds of sediment. This must have occurred again and again in the process of the formation of the 4,000 feet of Gaspé sandstone. The true nature of the plants of these fossil soils I had subsequently good opportunities of investigating, and the most important results, in the discovery of the plants of my genus Psilophyton, are embodied in the restoration of $P$. princeps in Fig. I. This remarkable plant, the oldest land plant known in America, since it extends through the Upper Silurian as well as the Devonian, presents a creeping horizontal rhizome or root-stock, from the upper side of which were given off slender branching stems, sometimes bearing rudimentary leaves, and crowned, when mature, with groups of gracefully nodding oval spore-cases. The root-stocks must in many cases have matted the soils in which they grew into a dense mass of vegetable matter, and in some places they accumulated to a sufficient extent to form layers of coaly matter, one of which on the south side of Gaspé Bay is as much as three inches in thickness, and is the oldest coal known in America. More usually the root-beds consist of hardened clay or fine sandstone filled with a complicated net-work or with parallel bands of rhizomes more or less flattened and in various states of preservation. In all probability these beds were originally swampy soils. From the surface of such a root-bed there arose into the air countless numbers of slender but somewhat woody stems, forming a dense mass of vegetation three or four feet in height. The stems, when young or barren, were more or less sparsely clothed with thick, short, pointed leaves, which, from the manner in which they penetrate the stone, must have been very rigid. At their extremities the stems were divided into slender branches, and these when young were curled in a crosier-like or circinate manner. When mature they bore at the ends of small branchlets pairs of oval sacs or spore-cases. The rhizomes when well preserved show minute markings, apparently indicating hairs or scales, and also round areoles with central spots, like those of Stigmaria, but

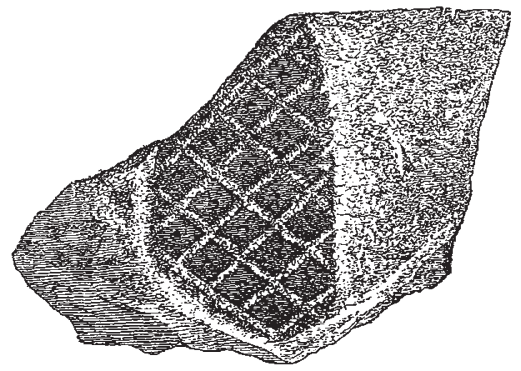

F1G. 2.-Leptophlenm rhombicumn-a Lycopodiaceous tree of the Devonian.

not regularly arranged. These curious plants are unlike anything in the actual world. I have compared their fructification with that of the Pilularize or Pillworts, a comparison which has also occurred to Dr. Hooker. On the other hand, this fructification is borne in a totally different manner from that of Pilularia, and in this respect rather resembles some ferns; and the young stems by themselves would be referred without hesitation to Lycopodiacer. In short, Psilophyton is a generalised plant, presenting characters not combined in the modern world, and, perhaps illustrating what seems to be a general law of creation, that in the earlier periods low forms assumed characteristics subsequently confined to higher grades of being.

A second species of Psilophyton ( $P$. robustius), also abundant at Gaspé, shows stouter stems than the former, more abundantly branching and with smaller leaves, often quite rudimentary. Its spore-cases are also of different form and borne in dense clusters on the sides of the stem. Masses of very slender branching filaments appear to indicate a third species ( $P$. elegans) which is also found in the Devonian of St. John, New Brunswick. These species of Psilophyton occur both in the lower and middle Devonian, and, as will be mentioned in the sequel, they extend also into the Upper Silurian.

Decorticated and flattened stems of Psilophyton cannot be readily recognised, and except when their internal structure has been preserved, might be mistaken for algæ, a mistake which I believe has in some instances been 
made. Specimens of the barren stems (var. ornatum) might readily be referred to the genius Lycopodites.

Another genus of generalised type is that named by Haughton Cyclostigma. As found at Gaspé it presents slender stems with rounded scars, placed either spirally or in transverse rows, and giving origin to long rigid leaves. It had a slender axis of scalariform vessels, and fructification of the form of elongated spikes or strobiles is found with it. In many respects these plants resembled Psilophyton, and their affinities were distinctly Lycopodiaceous. Specimens from Ireland, in the Museum of the Geological Society, kindly shown to me by Mr. Etheridge, appear to show that in that country these plants attained the dimensions of trees, and had roots of the nature of Stigmaria. Mr. Carruthers has even suggested that they may be allied to Syringodendron, a group of Carboniferous trees connected with the Sigillaria.

The genus Lycopodites is represented by a trailing species, bearing numerous oval strobiles (L.Richardsoni), a species quite close to many modern club-mosses ( $L$. Matthewi), and a remakable pinnate form (L. Vanuxemii), which, though provisionally placed here, has been variously conjectured to resemble Ferns, Cycads, Algæ, and Graptolites. But the most remarkable Lycopodiaceous plants are the gigantic arboreal Lepidodendra, plants

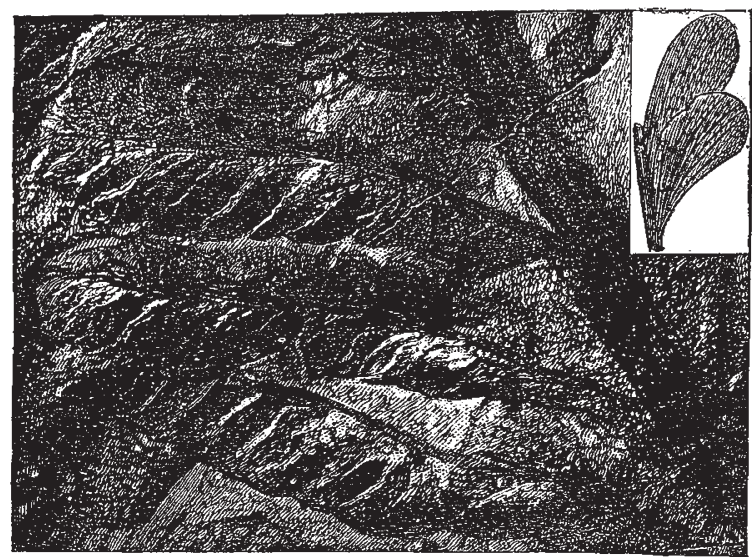

FIG. 3.-Cyclopteris (Archceopteris) Facksoni-a Devonian Fern, the American representative of $C$. Hibernicus.

which, while they begin in the Middle Devonian, become eminently expanded in numbers and magnitude in the Carboniferous. The common species in Eastern America (L. Gaspianum) was of slender and delicate form, very elegant, but probably not of large size. In the same family 1 would place my new genus Leptophleum, a portion of whose curiously-marked bark is represented in Fig. 2.

The Calamites, afterwards so largely developed in the Carboniferous, and to be replaced by true Equiseta in the Trias, make their first appearance in a large species (C. inornatum) in the Lower Devonian, and are represented in the middle and upper parts of the system by two other species, which extend upward into the Carboniferous. They are also represented in the Devonian of Germany and of Devonshire. The peculiar type indicated by the internal casts known as Calamodendron is likewise found in the Devonian.

More beautiful plants were the Asterophyllites, with more slender and widely branching stems, and broader leaves borne in whorls upon their branches. These plants have been confounded with leaves of Calamites, from which, however, they differ in form and nervation, and in the want of the oblique interrupted lines common to the true leaves of Calamites and to the branchlets of Equisetum. The Asterophyllites, and with them a species of Sphenophyllum, appear in the Middle Devonian.
No plants of the modern world are more beautiful in point of foliage than the Ferns, and of these a great number of species occur in the Middle and Upper Devonian. I must refer for details to my more full memoirs on the subject, and in the present paper shall content myself with a few general statements. Some of the generic forms of the Devonian, and perhaps a few of the species, extend into the Carboniferous; others are peculiar to the Devonian; and among these, forms allied to the modern Hymenophyllum and Trichomanes appear to prevail. One remarkable type, Cyclopteris (Archceopteris) Hibernicus, with its American allies, C. Facksoni, \&c., extends in the Upper Devonian over both continents, yet is wanting in the Carboniferous. Tree ferns also existed in the Devonian. Two species have been found by Dr. Newberry in Ohio, and remarkable erect trunks have been obtained by Professor Hall from Gilboa, in the State of New York. The latter are surrounded by aerial roots, and thus belong to the genus Psaronius; a genus which, however, must be artificial, since in modern tree ferns aerial roots often clothe the lower part of the stems while absent from the upper part. The only indication as yet of a tree fern in the Old World is the Caulopteris Peachii, of Salter, from the Old Red of Scotland. It is further remarkable that the ferns of the genus Archæopteris are much more large and luxuriant in Ireland than in America, and that in both regions they characterise the upper member of the system.

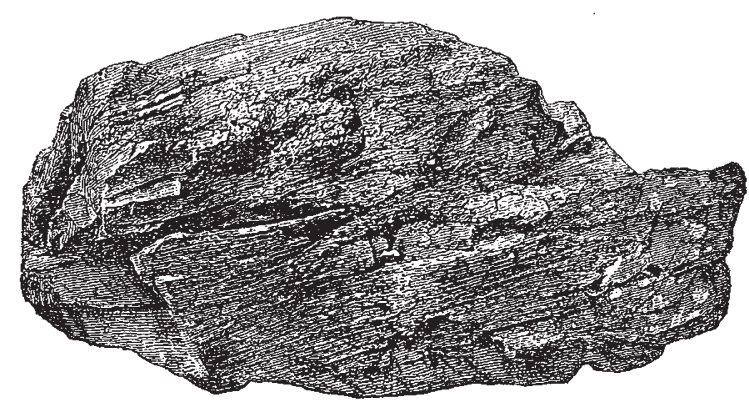

FrG. 4.-Prototaxites Logani-the oldest known tree. (Fragment of the trunk, much ređuced.)

Of the plants of the Palæozoic world, none are more mysterious than those known to us by the name Sigillarice, and distinguished by the arrangement of their leaves in vertical series, on stems and branches often ribbed longitudinally, and by the possession of those remarkable roots furnished with rootlets regularly articulated and spirally arranged, the Stigmariz. It seems evident that this group of plants included numerous species, differing from each other both in form and structure. Still, as a whole, they present very characteristic forms dissimilar from those of their contemporaries, and still more unlike anything now living. I believe that many of them were Gymnosperms, or at the least, Acrogens with stems as complicated as those of Gymnosperms. In the Carboniferous period these plants have a close connection with the occurrence of coal. Nearly every bed of this mineral has under it a "Stigmaria underclay," which is a fossil soil on which a forest of Sigillariæ has grown, and the remains of these trees are very abundant in the coal and the accompanying beds. Hence the Sigillariæ of the coal-period are regarded as the plants most important in the accumulation of coal. In the Devonian, as far as we yet know, they did not attain to this utility, and in the lower part of the system at least, the rhizomata of Psilophyton seem to have occupied the place afterwards held by the Stigmariæ. In connection with this, it is to be remarked that the Sigillaria of the Erian 
period seem to have been few, and of small dimensions in comparison with those of the coal.

Rising still higher in the vegetable kingdom, and arriving at unquestionable Gymnosperms, we find in the Devonian of Eastern America, and also, I believe, in that of Scotland and Germany, trunks which may be referred to Coniferæ. In the Middle and Upper Devonian these present the structure of modern Araucarian pines, or that modification of it belonging to the Carboniferous trees of the genus Dadoxylon. In the Lower Devonian we have what seems to be a simplification of the Coniferous structure, in the cylindrical wood-cells, marked only with spiral threads, found in the genus Prototaxites. These trees are very abundant as drift trunks in the Lower Devonian, down almost to its bottom beds, and sometimes attain to a diameter of three feet. Though of a structure so lax that it is comparable only with the youngest stems of ordinary Coniferre, these trees must have been durable, and they are furnished both with medullary rays and rings of annual growth. Unfortunately we know nothing of their foliage or fruit. Fig. 4 represents a fragment of the wood of one of these trees, mineralised by infiltration of the tissues with silica, so that the structure is preserved.

But for one little fragment of wood, we should have had no indication of the existence in the Erian of any trees of higher organisation than the Conifers. This fragment, found by Professor $\mathrm{Hall}$ at Eighteen-mile Creek, Lake Erie, has the dotted vessels characteristic of ordinary Exogens, and unquestionably indicates a plant of the highest kind of organisation. Until confirmed by other facts, this discovery may be received with doubt, but I believe it can be relied on.

Our knowledge of the flora of the Upper Silurian is at present nearly in the same state with that of the Middle and Lower Devonian ten years ago. I know in the Upper Silurian of Canada but two species of Psilophyton, both apparently identical with Devonian forms. In England, besides the spore-cases known by the generic name Pachytheca, there exist in the collections of the Geological Survey fragments of wood and bark which I believe indicate two additional species. In Germany three or four species are known in rocks of this age. All of these plants appear to be Acrogens allied to Lycopodiaceæ. That these few species constitute the whole flora of the Upper Silurian we can scarcely believe. They occur in marine formations, and were probably drifted far from the somewhat limited land-surfaces which existed in the explored parts of the Upper Silurian areas. When we obtain access to deposits of this age formed in shallows or estuaries, we may hope to find a flora of greater richness ; and, judging from present indications, not dissimilar from that of the Lower Devonian.

With the exception of some remains which I believe to be of very doubtful character, the Lower Silurian has as yet afforded no remains of land plants, and in North America, at least, this is very significant, inasmuch as we have, in the Potsdam sandstone, extensive sandy flats of this period, in which we might expect to find drifted trunks of trees, if such had existed. But the search is not hopeless, and we may yet find some estuary deposit on the margin of the ancient Laurentian continent, in whose beds the plants of that old land may occur.

Lastly, for reasons stated in a paper lately published in the Proceedings of the Geological Society, I believe that the extensive deposits of graphite, which exist in the Laurentian of Canada, are of vegetable origin, and possibly in part produced by land plants, as yet altogether unknown to us. If the Palæozoic was the age of Acrogens, the Eozoic may have been that of Anophytes and Thallophytes. Its plants may have consisted of gigantic mosses and lichens, presenting us . with a phase of yegetable existence bearing the same relation to that of the Palæozoic, which the latter bears to that of more modera periods. But there is another and a more startling possibility, that the Laurentian may have been the period when vegetable life culminated on our planet, and existed in its highest and grandest forms, before it was brought into subordination to the higher life of the animal. The solution of these questions belongs to the future of geology, and opens up avenues not merely for speculation but also for practical work.

The above must be regarded as merely a sketch of the present aspect of the subject to which it relates. Details must be sought elsewhere.

\section{J. W. DAWSON}

\section{NOTES}

The Royal Commission on Scientific Instruction and the Advancement of Science has already begun work. A second meeting was held on the $3^{15 t}$ ult. at Devonshire House. Present : The Duke of Devonshire, K.G., chairman; the Marquis of Lans lowne; Sir J. Lubbock, Bart., M.P., F.R.S. ; Sir J.P. Kay Shuttleworth, Bart. ; Mr. B. Samueison, M.P.; Dr. Sharpey, Sec. R.S. ; Professor Huxley, F.R.S. ; Dr. W. A. Miller, Treas. R.S.; and the secretary, Mr. J. Norman Lockyer, F.R.S.

A MeEring of the Syndicate appointed to consider the ways and means of establishing a Chair of Experimental Physics at Cambridge was held on Tuesday last.

We may remind our Astronomical readers that the Visitation of the Royal Observatory at Greenwich takes place at 3 P.M. on Saturday.

THE annual meeting for the election of Fellows into the Royal Society was held this morning.

The Geographical Society of Paxis has bestowed a wellearned honour on our countryman, Mr. Alfred R. Wallace, by awarding him one of their gold medals for his researches in the Malay Archipelngo.

Ar the meeting of the French Academy, held on the $23 \mathrm{rd}$ ult., the following list of candidates for tlie place vacant by the death of Professor Magnus was presented by the Secret Committee :-I, Mr. Joule ; 2, MM. Angströrm, Billet, Dove, Grove, Henry, Jacobi, Lloyd, Riess, Stokes, Tyndall, Volpicelli, and Sir William Thomson.

THE Gresham lectures for the present week at the Gresham College, Basinghall Street, are by Dr. Symes Thompson, on the 2nd, $3^{\mathrm{rdl}}$, and $4^{\text {th }}$ of June, at 7 P.M., on "The Epidemics of the Middle Ages," on "Sedatives," and on "Narcotics." They are free to the public, and will be illustrated with diagrams, tables, and chemical experiments.

THE municipal administration of Paris has decided on publishing a series of documents on the history of the capital. The commission appointed for this purpose has placed at the head of its programme a sketch of the pre-historic epochs, and has entrusted this labour to $\mathrm{M}$. Belgrand, who is well known in the scientific world by his important works on the basin of Paris. In presenting to the Academy a resume of his work, he divides it into four parts-the diluvian epoch, the great water-courses of the age of stone, the history of the peat-mosses, and the palæontological history of the basin of the Seine during the quaternary epoch. Our Common Council of London lias a splendid oppor. tunity of distinguishing itself in the same way; is it too much to expect of such an august body?

WE perceive with great pleasure that the Radcliffe Library at Oxford is being adapted more completely to the wants of students of science. Students in any department of natural knowledge, who need scientific works, maps, or plans which they do not find in the library, are invited to record their wants in a book kept for the purpose. There is a standard microscope, by Powell and Lealand, attached to the library, for the comparison of ubjects with the illustrated works of the library. 